\title{
Estudio mediante AFM de la corrosión de aceros en disoluciones de fase acuosa del hormigón
}

\section{AFM study of steel corrosion in aqueous solutions in concrete}

\author{
B. Díaz-Benito(*), F. Velasco ${ }^{*}$, S. Guzmán(*), R. Calabrés(*)
}

Recepción/Received: 29-IV-10

Aceptación/Accepted: 3-XI-10

Publicado online/Online publishing: 19-XI-10

RESUMEN

Este trabajo estudia los primeros estados de la corrosión de un acero al carbono en una disolución que simula la existente en los poros del hormigón, sin carbonatar, con un $5 \%$ de $\mathrm{NaCl}$. Para ello, se ha empleado la técnica de microscopía de fuerza atómica (AFM), estudiando el comportamiento del material tras diferentes tiempos de inmersión, hasta 48 h, en la disolución. Estos datos se comparan con datos electroquímicos (potencial de corrosión y resistencia de polarización). El análisis de las imágenes y la evolución de la rugosidad con el tiempo muestran que el acero tiende inicialmente a pasivarse, pero la capa pasiva pierde rápidamente su carácter protector debido al ataque de los cloruros.

Palabras clave: acero, corrosión, microscopía de fuerza atómica (AFM).

\section{SUMMARY}

Early corrosion stages are studied in carbon steel by means of a solution simulating that contained in concrete pores. Non-carbonated solution contains $5 \% \mathrm{NaCl}$. The atomic force microscopy (AFM) technique is used to study material performance after different immersion times (up to $48 \mathrm{~h}$ ). Obtained data are compared to electrochemical ones (corrosion potential and polarization resistance). Analysis of images and roughness evolution along time shows that steel initially tends to reach passivity, although the passive layer rapidly loses its protective character due to chloride attack.

Keywords: steel, corrosion, atomic force microscopy (AFM).

\section{INTRODUCCIÓN}

Las técnicas electroquímicas se pueden emplear para evaluar la resistencia a corrosión de aceros corrugados cuando están embebidos en mortero y hormigón. Entre ellas, se encuentran la medida del potencial de las armaduras

\section{INTRODUCTION}

Electrochemical techniques can be used to evaluate corrosion resistance in corrugated steel when embedded in mortar and concrete. These techniques include rebar potential measurement (1) and the creation of potential

(*) Universidad Carlos III (Madrid, España).

Persona de contacto/Corresponding author: francisco.velasco@uc3m.es 
(1) y la creación de mapas de potenciales, o la medida de la resistencia de polarización $(2,3)$. Cuando se estudian disoluciones que simulan las contenidas en los poros del hormigón, se pueden emplear otras técnicas, como las curvas de polarización anódica (4). El empleo de la espectroscopía de impedancia electroquímica (EIS), tanto en disoluciones como en probetas de mortero (5), permite explicar los mecanismos de pasivación de los aceros en estos medios (4).

Es una realidad que cada día aparecen nuevas técnicas que permiten evaluar los mecanismos de corrosión y su medida en el campo de los materiales y, en particular, en aceros. Así, en los últimos años, en estructuras de hormigón armado, se ha propuesto el empleo de redes de fibra óptica para evaluar la corrosión (6), el empleo de técnicas de electromagnetismo (7) y emisión acústica (8) para evaluar el estado de aceros bajo tensión, o la fotoelasticidad para analizar la formación de grietas (9). En el caso de disoluciones que simulan la existente en los poros de hormigón, se ha propuesto la espectroscopía Raman in situ en aceros con un $9 \%$ de cromo (10), o el empleo de multielectrodos para evaluar la distribución de la corrosión en aceros al carbono o inoxidables (11).

Entre las técnicas más modernas, se encuentra la microscopía de fuerza atómica (AFM). La corrosión de metales puede requerir estudios topológicos mediante AFM. Estos aspectos juegan un papel importante desde la nucleación, a nivel nanométrico, hasta el crecimiento de las picaduras (12). El AFM permite actualmente cuantificar la topografía de una superficie con elevadas resoluciones laterales y verticales. Esta técnica se ha empezado a emplear en la monitorización de procesos de corrosión tan variados como el estudio de inhibidores en aceros (13), la resistencia a corrosión de aleaciones de aluminio en $\mathrm{HCl}$ (14), o la corrosión por picaduras en cobre (15).

En el caso de materiales de construcción, esta técnica se ha empleado para el estudio de la pasividad de un acero 316 en disoluciones saturadas de hidróxido cálcico (16) y para evaluar el efecto de disoluciones neutras de cloruros en aceros corrugados de alta resistencia (17). También se ha evaluado la corrosión en aceros de bajo carbono en disoluciones carbonatadas y sin carbonatar con cloruros (18), que han mostrado como esta técnica es capaz de medir la corrosión localizada y los procesos que tienen lugar. Si bien estos trabajos se han llevado a cabo a circuito abierto, existen también estudios a potenciales anódicos y catódicos (19) para estudiar las capas pasivas formadas en aceros dulces.

Los aceros embebidos en hormigón tienen una capa pasiva formada por una capa interior rica en $\mathrm{Fe}^{2+}$ y una exterior, rica en $\mathrm{Fe}^{3+}(19)$, aunque existen diferentes maps, as well as polarization resistance measurements $(2,3)$. Other techniques such as anodic polarization curves (4) can be used to study steels in solutions simulating those found in concrete pores. Electrochemical impedance spectroscopy (EIS) in both solutions and mortar samples (5) allows explaining the passivation mechanisms observed in steel subject to these media (4).

Almost everyday new techniques allow evaluating corrosion mechanisms and their measurement in the field of materials in general and of steels in particular. Thus, in recent years, optical fibre networks (6) have been proposed to evaluate corrosion in reinforced concrete structures. Besides, electromagnetism (7) and acoustic emission (8) techniques have also been proposed to evaluate the state of steel under strain. Also, photoelasticity has been proposed to analyse crack formation (9). In the case of solutions simulating that in concrete pores, in situ Raman spectroscopy has been proposed for steels containing $9 \% \mathrm{Cr}$ (10). Multielectrodes have also been proposed to evaluate corrosion in carbon steels or stainless steels (11).

AFM is among the most recent techniques. Metal corrosion may demand topological studies by means of AFM. These aspects play a significant role in a wide range of processes: from nucleation (at nanometric level) to pitting (12). AFM currently allows quantifying surface topography with high lateral and vertical resolution. This technique has begun to be used to monitor a wide range of corrosion processes -e.g., the study of inhibitors in steel (13), corrosion resistance in aluminium alloys in $\mathrm{HCl}(14)$, pitting corrosion of copper (15), etc.

In the case of construction materials, this technique has been used to study passivity in 316 steel in calciumhydroxide saturated solutions (16) and to evaluate the effect of neutral chloride solutions on high strength corrugated steels (17). Corrosion in low-carbon steels has also been assessed in both carbonated and noncarbonated chloride-containing solutions (18). This technique has been proven capable to measure localized corrosion and the processes involved. Nevertheless, these works were developed in open circuit. The passive layers in low-carbon steels have also been researched by studies on anodic and cathodic potential (19).

Concrete-embedded steels show a passive layer constituted by an inner layer rich in $\mathrm{Fe}^{2+}$ and an outer layer rich in $\mathrm{Fe}^{3+}$ (19). However, different theories have 
teorías al respecto. Estas capas deben estar formadas por granos de carácter nanométrico, y algunos modelos actuales de rotura de capa pasiva parten del hecho de la presencia de bordes de grano en la misma, por donde se inician las picaduras (20), como se ha visto por AFM. Esta rotura se debe fundamentalmente a la presencia de iones cloruro. Estos iones se adsorben localmente en la superficie acelerando la corrosión por picaduras, y los productos de corrosión pueden recubrir dichas picaduras (21), acidificando las mismas y favoreciendo su desarroIlo. La influencia de los iones cloruro en la despasivación del acero puede entenderse como el resultado del balance entre dos procesos en competencia: la estabilización (y reparación) de la capa pasiva por los iones hidroxilo y su rotura por parte de los iones cloruro (22). Cuando la actividad de los hidroxilo supera a la de los cloruros, el crecimiento de las picaduras puede detenerse (22).

Este trabajo tiene como objetivo el empleo de AFM para evaluar los estados iniciales de los procesos de corrosión de un acero al carbono en una disolución saturada de hidróxido cálcico con cloruros, comparando los resultados con los obtenidos por técnicas electroquímicas.

\section{MATERIALES Y MÉTODOS}

Se prepararon muestras planas de un acero ferrítico, de bajo carbono, de $8 \times 8 \mathrm{~mm}$. Este acero entra dentro de las composiciones recogidas para aceros corrugados en la norma UNE 36068. Dichas muestras fueron pulidas con una suspensión acuosa de polvo de alúmina de 0,3 $\mu \mathrm{m}$. Seguidamente, fueron introducidas en una disolución saturada de $\mathrm{Ca}(\mathrm{OH})_{2}$, con un $\mathrm{pH} \approx 12,6$, y con $5 \%$ de $\mathrm{NaCl}$. Las muestras fueron introducidas durante diferentes tiempos, desde 30 min hasta $48 \mathrm{~h}$. Al sacarlas, fueron lavadas con abundante agua destilada para eliminar cualquier resto previo a la evaluación mediante AFM, y secadas inmediatamente con aire.

Las medidas de AFM (NanoScope IV, Digital Instrument) se realizaron en aire, a temperatura ambiente. Las medidas fueron realizadas en modo de contacto intermitente (tapping mode) usando puntas de silicio MPP-11100 (TM Nanoprobe, Veeco). La constante de fuerza de estas puntas fue de $40 \mathrm{~N} / \mathrm{m}$. Se tomaron imágenes de altura (topografía) a partir de las cuales se realizaron análisis de rugosidad. Cada uno de los resultados de rugosidad se obtendrá de la media de al menos cuatro medidas en distintos puntos de cada muestra. En todos los casos, el área procesada tenía una dimensión de $5 \times 5 \mu \mathrm{m}$. Como comparación, se prepararon y midieron muestras del mismo material, en el mismo estado superficial, en una disolución saturada de $\mathrm{Ca}(\mathrm{OH})_{2}$, sin cloruros. Asimismo, se evaluaron muestras de material en estado pulido, sin haber sido introducidas en ninguna disolución (etiquetadas en las figuras del trabajo como 0 h). been contributed so far on this issue. These layers must be formed by nanometric grains. Thus, some current models on passive-layer breakdown start from the observation of grain boundaries, which are preferred sites for the onset of corrosion (20), as observed by AFM. This breakdown is mainly due to the presence of chloride ions. These ions are locally adsorbed on the surface, thus accelerating pitting corrosion. Moreover, corrosion products can cover pitted areas (21), hence acidifying them and therefore favouring their development. The influence of chloride ions on steel de-passivation can be understood as a balance between two competing processes: stabilization (and reparation) of the passive layer by hydroxyl ions, and its breakdown by chloride ions (22). Pitting is likely to cease when the activity of hydroxyls exceeds that of chlorides (22).

The present work is aimed at the use of AFM to evaluate the initial stages of corrosion processes in carbon steel in a $\mathrm{Ca}(\mathrm{OH})_{2}$-saturated chloride-containing solution. The obtained results are compared to those obtained with electrochemical techniques.

\section{EXPERIMENTAL PROCEDURE}

$8 \times 8 \mathrm{~cm}$, flat samples of low-carbon, ferritic steel were prepared. This steel meets the composition demanded by the standard UNE 36068 for corrugated steel. The samples were polished with an aqueous suspension of alumina powder $(0.3 \mu \mathrm{m})$ and subsequently introduced in a $\mathrm{Ca}(\mathrm{OH})_{2}$ saturated solution ( $\left.\mathrm{pH} 12.6\right)$ with $5 \% \mathrm{NaCl}$. The samples were introduced for different amounts of time (from 30 min to $48 \mathrm{~h}$ ), being subsequently washed with abundant distilled water to eliminate any previous trace by means of AFM, and air dried.

AFM measurements (NanoScope IV, Digital Instrument) were preformed in air at room temperature. Measurements were performed with the tapping mode using MPP-11100 silicon probes (TM Nanoprobe, Veeco). Constant force in these probes was $40 \mathrm{~N} / \mathrm{m}$. Height images (topography) were taken and allowed roughness analysis. Each roughness result is obtained from the mean of at least four measurements at different places in each sample. In all cases the dimension of the processed area was $5 \times 5 \mu \mathrm{m}$. For comparison purposes, samples of the same material were prepared and measured in the same surface state in a chloride-free $\mathrm{Ca}(\mathrm{OH})_{2}$ saturated solution. Likewise, polished samples were also evaluated without any immersion (labelled as $0 \mathrm{~h}$ in the enclosed figures). 
Finalmente, se realizaron medidas electroquímicas, monitorizando el potencial de corrosión ( $E_{\text {corr }}$ ) del mismo acero en ambas disoluciones, y midiendo la resistencia de polarización $\left(R_{p}\right)$ a diferentes tiempos, con el fin de comparar los resultados de AFM con los de $E_{\text {corr. }}$.

\section{RESULTADOS}

La Figura 1 muestra algunas de las imágenes de AFM tomadas a diferentes tiempos en los aceros tras su inmersión en la disolución saturada de $\mathrm{Ca}(\mathrm{OH})_{2}$ con $5 \%$ de $\mathrm{NaCl}$. Estas imágenes muestran, de forma cualitativa, el proceso que está teniendo lugar en el acero, desde el estado de pulido ( $0 \mathrm{~h}$, antes de ser introducida en ninguna disolución) hasta las $36 \mathrm{~h}$. Tras el pulido, la pequeña rugosidad observada es consecuencia del propio proceso de pulido, realizado con una suspensión de polvo de alúmina de 0,3 $\mu \mathrm{m}$. De forma cualitativa, se puede apreciar cómo el ataque progresa con el tiempo de inmersión en la disolución, haciéndose cada vez la superficie más rugosa.
Finally, electrochemical measurements were performed monitoring the corrosion potential ( $E_{\text {corr }}$ ) of the same steel in both solutions and measuring polarization resistance $\left(R_{p}\right)$ at different times so as to compare AFM and $E_{\text {corr }}$ results.

\section{RESULTS}

Figure 1 shows some of the AFM images taken at different times in steels after their immersion into a $\mathrm{Ca}(\mathrm{OH})_{2}$ saturated solution with $5 \% \mathrm{NaCl}$. Qualitatively, these images show the process observed in steel from polishing ( $0 \mathrm{~h}$, prior to immersion) up to $36 \mathrm{~h}$. After polishing, the slight roughness observed is the result of the polishing process itself, performed with an aluminapowder suspension $(0.3 \mu \mathrm{m})$. Qualitatively, the attack is observed to progress with immersion time. Thus, the surface gets progressively rougher.

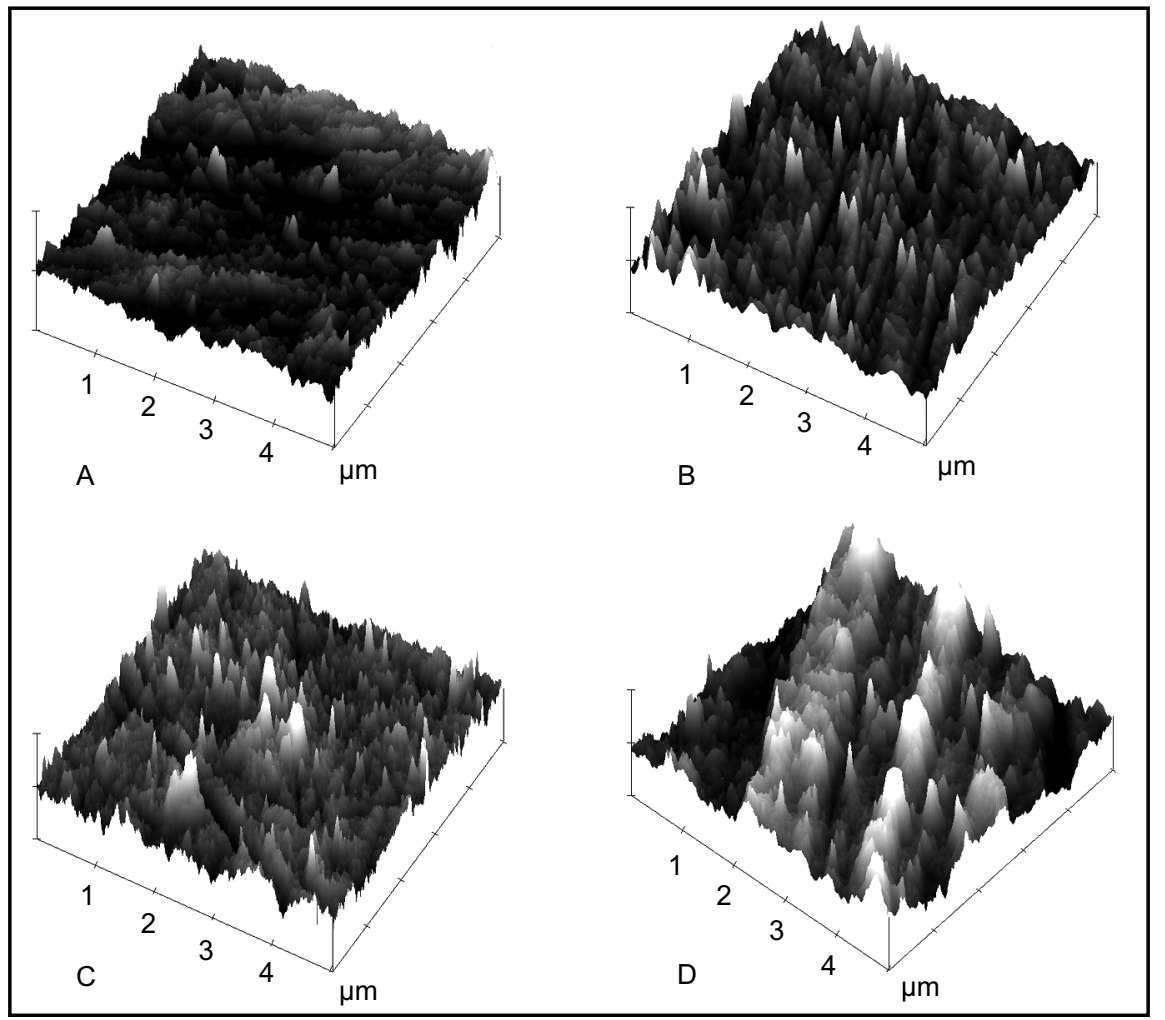

Figura 1. Imágenes de AFM tomadas en los aceros tras diferentes tiempos de inmersión en disoluciones saturadas de $\mathrm{Ca}(\mathrm{OH})_{2}$ con $5 \%$ de cloruros. A) $\left.\left.0 \mathrm{~h}, \mathrm{~B}\right) 1 \mathrm{~h}, \mathrm{C}\right) 8 \mathrm{~h}$ y D) $36 \mathrm{~h}$. Las divisiones del eje $\mathrm{z}$ son, en todos los casos, $30 \mathrm{~nm} / \mathrm{div}$. Figure 1. AFM images of the steel alter different immersion times in $\mathrm{Ca}(\mathrm{OH})_{2}$ saturated solutions with $5 \%$ of chlorides. A) $0 h, B) 1 h, C) 8 h$, and D) $36 \mathrm{~h}$. Z-axis divisions are $30 \mathrm{~nm} /$ div in all cases.

La Figura 2 recoge el registro de algunos perfiles tomados de forma aleatoria sobre dichas imágenes de AFM, para diferentes tiempos, representando con mayor claridad el efecto que tiene lugar sobre la superficie del acero. Como
Figure 2 shows the register of some profiles taken randomly on these AFM images for different immersion times, thus representing the effect of immersion time on steel surface. Sample roughness can be observed to 


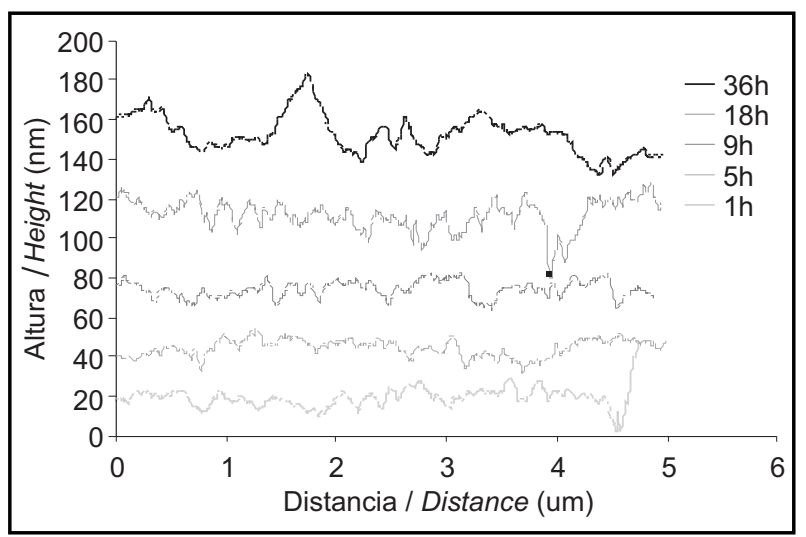

Figura 2. Perfiles tomados de forma aleatoria de las imágenes de AFM obtenidas en los aceros.

Figure 2. Random profiles from AFM images taken on steels.

se aprecia claramente, la rugosidad de la muestra aumenta con el tiempo de inmersión en la disolución que simula la contenida en los poros del hormigón que contiene $\mathrm{NaCl}$, especialmente a tiempos superiores a las $5 \mathrm{~h}$.

Las Figuras 3 y 4 muestran la evolución de la rugosidad con el tiempo de inmersión. El parámetro Rmax (rugosidad máxima, Figura 3) mide la diferencia entre la altura máxima de pico y la profundidad máxima de valle del perfil de rugosidad, mientras que Ra (rugosidad media, Figura 4) es el valor promedio aritmético de los valores absolutos de las distancias del perfil de rugosidad de la línea intermedia de la longitud de medición. En el caso de las disoluciones sin cloruros, se observa como la rugosidad máxima (Figura 3) varía fuertemente desde el estado de pulido $(0 \mathrm{~h})$, y en 30 min se obtiene un valor de rugosidad, próximo a los $60 \mathrm{~nm}$, que va creciendo de forma muy ligera hasta el final del ensayo $(48 \mathrm{~h})$, mientras que en el caso de la rugosidad media (Figura 4), ésta permanece constante durante todo el ensayo.

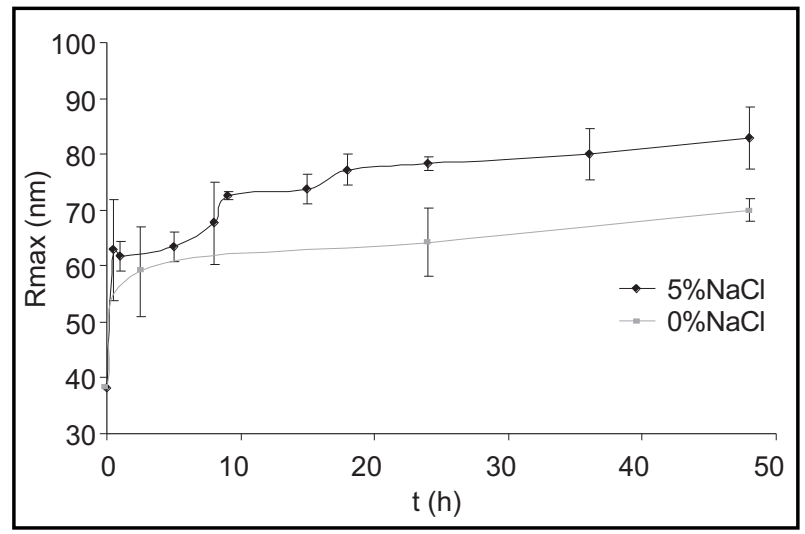

Figura 3. Evolución de la rugosidad máxima Rmax en los aceros con el tiempo de inmersión en disoluciones saturadas de $\mathrm{Ca}(\mathrm{OH})_{2}$ sin cloruros y con $5 \%$ de cloruros.

Figure 3. Maximum roughness (Rmax) evolution on steels with immersion time, in $\mathrm{Ca}(\mathrm{OH})_{2}$ saturated solutions without and with $5 \%$ chlorides. increase as immersion time does (particularly over $5 \mathrm{~h}$ ) when samples are immersed in $\mathrm{NaCl}$ containing solution simulating that in concrete pores.

Figures 3 and 4 show the evolution of roughness along immersion time. Rmax (maximum roughness, Figure 3) measures the difference between maximum peak height and maximum valley depth observed in the roughness profile, while Ra (average roughness, Figure 4) is the arithmetic mean value of the absolute values of the distances in the roughness profile of the intermediate line of measurement length. In case of chloride-free solutions, strong variations are observed in maximum roughness (Figure 3): from polishing $(0 \mathrm{~h}$ ), after $30 \mathrm{~min}$ (around $60 \mathrm{~nm}$ ), and slightly increasing afterwards up to the end of the test ( $48 \mathrm{~h}$ ), while constant values are observed along the whole test for average roughness (Figure 4).

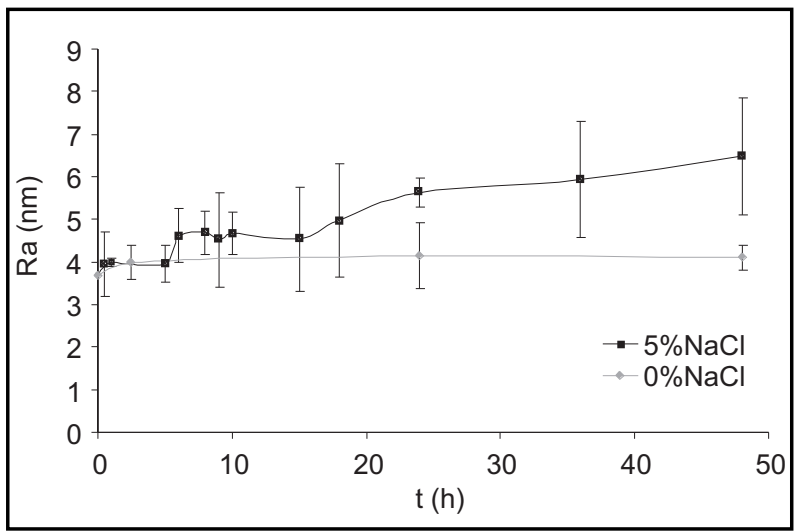

Figura 4. Evolución de la rugosidad media Ra en los aceros con el tiempo de inmersión en disoluciones saturadas de $\mathrm{Ca}(\mathrm{OH})_{2}$ sin cloruros y con $5 \%$ de cloruros.

Figure 4. Average roughness ( $R a$ ) evolution on steels with immersion time, in $\mathrm{Ca}(\mathrm{OH})_{2}$ saturated solutions without and with $5 \%$ chlorides. 
En el caso de la disolución saturada de $\mathrm{Ca}(\mathrm{OH})_{2}$ con $5 \%$ de $\mathrm{NaCl}$, la rugosidad máxima (Figura 3) también varía desde el estado de pulido $(0 \mathrm{~h})$, y en $30 \mathrm{~min}$ se obtiene un valor de rugosidad, próximo a los $62 \mathrm{~nm}$, que se mantiene más o menos estable hasta las $5 \mathrm{~h}$ de inmersión. A partir de ese instante, la rugosidad va aumentando de forma progresiva. En el caso de la rugosidad media (Figura 4), el efecto inicial es menos pronunciado, aunque existe. De nuevo, a partir de las $5 \mathrm{~h}$, la rugosidad vuelve a aumentar, coincidiendo con lo observado en el parámetro Rmax.

La Figura 5 muestra datos referentes a la cantidad (porcentaje) de área que presenta una rugosidad determinada, medida mediante AFM. En este caso, los datos corresponden a picos de altura mayor a 40, 50 ó $60 \mathrm{~nm}$, medidos desde el valle más profundo de cada perfil. Estos resultados muestran un crecimiento hasta las $24 \mathrm{~h}$ de ensayo, decreciendo desde ese momento.
In the case of the $\mathrm{Ca}(\mathrm{OH})_{2}$ saturated solution with $5 \%$ $\mathrm{NaCl}$, maximum roughness (Figure 3) also varies from polishing $(0 \mathrm{~h})$, after $30 \mathrm{~min}$ (around $62 \mathrm{~nm}$ ), and roughly keeps stable afterwards (up to $5 \mathrm{~h}$ ). From that moment onwards, roughness increases progressively. In the case of average roughness (Figure 4), the initial effect is less pronounced but observable. After $5 h$, roughness also increases, in agreement with that observed for Rmax.

Figure 5 shows data referred to the amount (ratio) of area showing a particular degree of roughness, measured with AFM. In this case, data correspond to height peaks over 40,50 or $60 \mathrm{~nm}$, measured from the deepest valley in each profile. These results show growth during the first 24 testing hours; while straight decrease is observed afterwards.

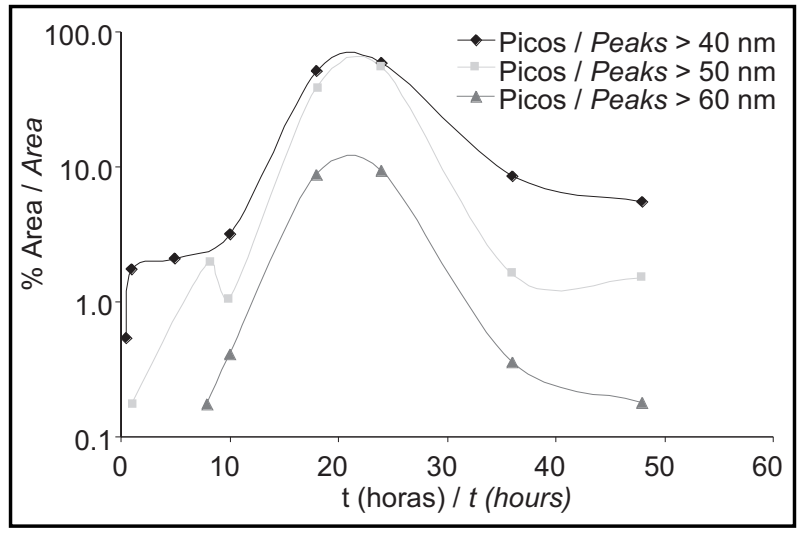

Figura 5. Porcentaje del área evaluada cuya altura es mayor a 40, 50 ó $60 \mathrm{~nm}$, medidos desde el valle más profundo del perfil, en los aceros tras su inmersión en la disolución saturada de $\mathrm{Ca}(\mathrm{OH})_{2}$ con $5 \%$ de cloruros.

Figure 5. Percentage of evaluated area with a height higher than 40,50 or $60 \mathrm{~nm}$, measured from the deepest valley of the profile, on steels after their immersion in $\mathrm{Ca}(\mathrm{OH})_{2}$ saturated solutions with $5 \%$ chlorides.

Finalmente, los resultados de la evolución del potencial de corrosión y resistencia de polarización con el tiempo se muestran en las Figuras 6 y 7. Como se puede apreciar, los valores de potencial medidos en ambas disoluciones son los esperados. El material en la disolución sin cloruros tiende a alcanzar valores de $\mathrm{E}_{\text {corr }}$ compatibles con la pasivación. Sin embargo, el material, en la disolución con cloruros, se mantiene en valores de potencial activos. En cuanto a las $\mathrm{R}_{\mathrm{p}}$, se puede apreciar como aumentan con el tiempo para la disolución sin cloruros, y disminuye en la que tiene cloruros, reflejando la pasividad y actividad del material, respectivamente. Además, hay dos órdenes de magnitud en los valores de $R_{p}$ entre ambas disoluciones.
Finally, Figure 6 and 7 show the obtained results on the evolution of corrosion potential and polarization resistance along time. The potential values measured in both solutions are as expected. The material in the chloride-free solution tends to reach $E_{\text {corr }}$ values compatible with passivation. However, the material in the chloride-containing solution keeps showing active potential values. $R_{p}$ can be observed to increase along time in the chloride-free solution and to diminish in the chloride-containing solution, thus reflecting material passivity and activity, respectively. Besides, a difference of two orders of magnitude can be observed between the $R_{p}$ values of both solutions. 


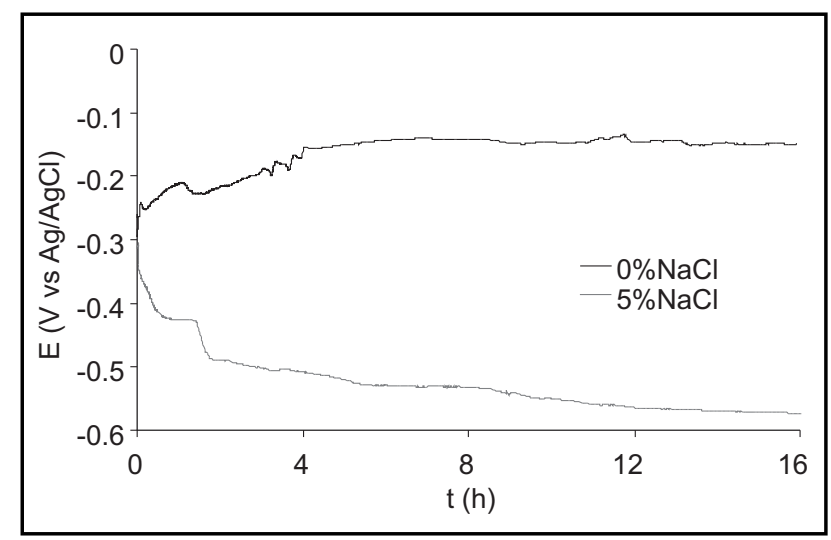

Figura 6. Evolución del potencial de corrosión en el acero pulido con el tiempo de inmersión en disoluciones saturadas de $\mathrm{Ca}(\mathrm{OH})_{2}$ con 0 y $5 \%$ de cloruros.

Figure 6. Corrosion potential evolution on polished steel with immersion time in $\mathrm{Ca}(\mathrm{OH})_{2}$ saturated solutions with 0 and $5 \%$ chlorides.

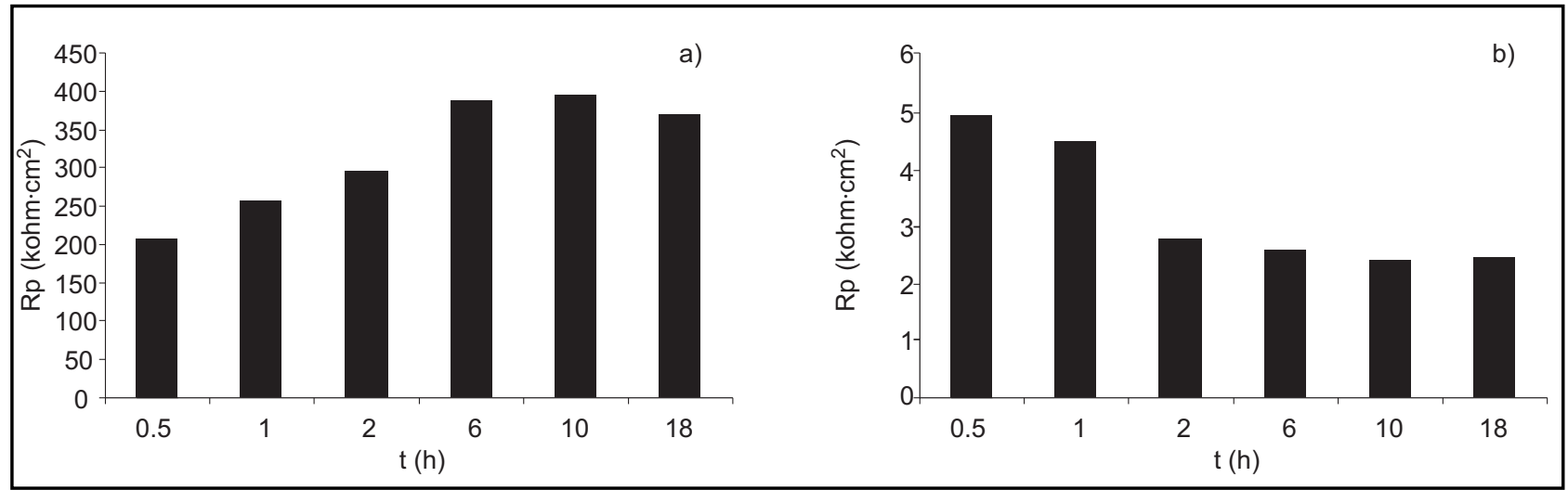

Figura 7. Evolución de la resistencia de polarización en el acero pulido con el tiempo de inmersión en disoluciones saturadas de $\mathrm{Ca}(\mathrm{OH})_{2}$ con (a) 0 y (b) $5 \%$ de cloruros.

Figure 7. Polarization resistance evolution on polished steel with immersion time in $\mathrm{Ca}(\mathrm{OH})_{2}$ saturated solutions with (a) 0 and (b) $5 \%$ chlorides.

\section{DISCUSIÓN}

Considerando la imagen a tiempo cero, antes de inmersión en ninguna disolución, el acero pulido muestra rugosidad a escala nanométrica, característica del pulido manual con alúmina (Figura 1a).

La rugosidad del acero aumenta casi inmediatamente tras su inmersión en la disolución con $5 \%$ de $\mathrm{NaCl}$ que simula la contenida en los poros del hormigón, y tras $1 \mathrm{~h}$, alcanza un valor que se mantiene constante hasta las $5 \mathrm{~h}$ de inmersión, como muestran las rugosidades máxima (Figura 3) y media (Figura 4). Este ligero aumento de la rugosidad ya se apreciaba de forma cualitativa en la Figura 1b, al comparar con el acero pulido (Figura 1a). Sin embargo, los perfiles son aún poco rugosos, como se aprecia en los perfiles extraídos de las medidas realizadas a 1 y $5 \mathrm{~h}$ (Figura 2). Este fenómeno puede estar relacionado con una cierta tendencia inicial a la pasivación del acero, aunque los datos electroquímicos no lo muestren.

\section{DISCUSSION}

Considering the image at $0 \mathrm{~h}$ (prior to immersion), polished steel shows roughness at nanometric scale, which characterizes manual alumina polishing (Figure 1a).

Steel roughness increases almost immediately after immersion in the solution which simulates the solution in concrete pores with $5 \% \mathrm{NaCl}$. After $1 \mathrm{~h}$, it reaches a value which holds constant up to $5 h$, as shown by maximum (Figure 3) and average (Figure 4) roughness values. This slight increase in roughness was already observed qualitatively in Figure $1 \mathrm{~b}$ relative to polished steel (Figure 1a). However, profiles are still scarcely rough, as observed in the profiles drawn from the measurements performed $1 \mathrm{~h}$ and $5 \mathrm{~h}$ after immersion (Figure 2). This phenomenon can be related to a certain initial tendency of steel to passivation, although it is not shown by electrochemical data. Steel tends to passivate 
Los aceros tienden a pasivarse en disoluciones sin carbonatar, tal y como indica el diagrama de Pourbaix, debido al pH altamente alcalino que presentan estas disoluciones. Esta pasivación implica la formación de óxidos e hidróxidos de hierro, más o menos hidratados, con un grado variable de $\mathrm{Fe}^{2+}$ y $\mathrm{Fe}^{3+}$ (19). El crecimiento de esta capa pasiva, de forma epitaxial, se puede apreciar en los perfiles mostrados (Figura 1), tal y como ocurre en aceros pretensados en disoluciones neutras de cloruros (17). Este crecimiento de la capa pasiva se ha mostrado también mediante medidas de $\mathrm{E}_{\mathrm{corr}}$ en disoluciones que simulan las contenidas en hormigón a tiempos breves (23). Este crecimiento de óxidos e hidróxidos provoca un aumento de rugosidad sobre la superficie, tanto máxima (Figura 3) como media (Figura 4), manteniéndose ambos valores muy estables. El hecho de que la rugosidad media Ra (Figura 4) apenas varíe implica que ese aumento de la rugosidad se debe a crecimientos puntuales de los óxidos, como puede interpretarse de los datos de la rugosidad máxima, y no a un aumento fuerte de la rugosidad, ya que Ra representa más el valor medio frente a crecimientos puntuales que detecta Rmax.

Estos resultados son compatibles con los que se muestran en la Figura 5. Para los tiempos estudiados, la cantidad de área afectada por una rugosidad elevada es muy pequeña. Sin embargo, dado que la rugosidad máxima (Figura 3) es ligeramente superior a $60 \mathrm{~nm}$, sí que se puede apreciar en los picos evaluados de no demasiada altura (mayor de $40 \mathrm{~nm}$ ) la misma tendencia anteriormente indicada: aumento hasta la hora de inmersión y mantenimiento hasta las $5 \mathrm{~h}$. En cualquier caso, la estabilidad de la pasividad en estos tiempos iniciales es limitada: el $\mathrm{E}_{\text {corr }}$ (Figura 6) no alcanza los valores de pasividad que se alcanzan en disoluciones sin carbonatar exentas de cloruros. Sin embargo, es destacable que durante este estado inicial, el potencial se mantiene constante.

Además, el comportamiento del acero en la disolución sin cloruros es prácticamente similar en estos tiempos de inmersión (Figuras 3 y 4), corroborando los fenómenos anteriormente comentados. El acero inmerso en la disolución sin cloruros tiende a pasivarse casi inmediatamente, como muestran los valores de $\mathrm{E}_{\text {corr }}$ (Figura 6). Además, los valores de $R_{p}$ (Figura 7a) son compatibles con ella, aumentando con el tiempo hasta su estabilización. En este caso, no existe un paralelismo total entre $R_{p}$ y rugosidad; hay que tener en cuenta que miden propiedades diferentes, $y$ si bien la capa de óxido/hidróxido protectora crece rápidamente (en 30 min alcanza un valor estable, según los datos de AFM), en ella pueden seguir produciéndose transformaciones químicas como muestran los valores de $E_{\text {corr }}$ y $R_{p}$. De forma similar, para la disolución con un $5 \%$ de $\mathrm{NaCl}$ no existe ese paralelismo. Los valores de rugosidad son compatibles con la tendencia natural a la protección del acero en un medio de alta alcalinidad como el ensayado; sin in non-carbonated solutions, as shown by the Pourbaix diagram, due to the highly alkaline $\mathrm{pH}$ of these solutions. This passivation involves the formation of more or less hydrated iron oxides and hydroxides with a variable degree of $\mathrm{Fe}^{2+}$ and $\mathrm{Fe}^{3+}$ (19). Epitaxial growth in this passive layer can be observed in the profiles shown in Figure 1, like in pre-stressed steels in chloridecontaining neutral solutions (17). This growth in the passive layer has also been shown by $E_{\text {corr }}$ measurements in concrete-simulating solutions at short times (23). This growth of oxides and hydroxides leads to increased maximum (Figure 3) and average (Figure 4) surface roughness; both values remain rather stable. The scarce variation observed in average roughness ( $R a$ ) means that this increase in roughness is due to specific oxide growths, as it can be interpreted from maximum roughness data, and not to a strong increase in roughness, since $R$ a represents better the average value vs. the specific growths detected by Rmax.

These results are compatible with those in Figure 5. For the studied times, the amount of area affected by high roughness is small. However, given that maximum roughness (Figure 3) is slightly over $60 \mathrm{~nm}$, the aforementioned tendency can be observed in the mediumheight peaks studied (over $40 \mathrm{~nm}$ ): it increases until immersion and holds constant up to $5 \mathrm{~h}$. Anyway, the stability of passivity in these initial stages is limited: $E_{\text {corr }}$ (Figure 6) does not reach the passivity values reached in non-carbonated chloride-free solutions. However, it must be highlighted that the potential holds constant during this initial stage.

Besides, the behaviour of steel in the chloride-free solution is practically similar for these immersion times (Figures 3 and 4), thus corroborating the previouslymentioned phenomena. The steel immersed in the chloride-free solution tends to passivate almost immediately, as shown by $E_{\text {corr }}$ values (Figure 6). Besides, $R_{p}$ values (Figure 7a) are compatible with this, increasing up to their stabilization. No relation is observed in this case between $R_{p}$ and roughness. It should be borne in mind that different properties are measured. Although the protective oxide/hydroxide layer grows quickly (a stable state is reached within 30 min, according to AFM data), chemical transformations keep taking place, as shown by $E_{\text {corr }}$ and $R_{p}$ values. Similarly, no parallelism was found for the solution with $5 \% \mathrm{NaCl}$. Roughness values are compatible with the natural trend to steel protection in a highly alkaline medium as the one tested in the present study. However, even at these so 
embrago, incluso a esos tiempos tan breves, el acero no alcanza un estado de pasivación completa, y los resultados electroquímicos muestran cómo están teniendo lugar transformaciones en la superficie del acero.

Sin embargo, a partir de las $5 \mathrm{~h}$ de inmersión (aproximadamente), el comportamiento del acero en ambas disoluciones difiere notablemente. Como se aprecia con claridad, el acero inmerso en una disolución sin cloruros mantiene valores de rugosidad media (Figura 4) prácticamente constantes, indicativos de escasa variación en la pasividad. Sólo se aprecia un ligero aumento de rugosidad máxima (Figura 3) a partir de las $24 \mathrm{~h}$ de inmersión, aunque dado que las barras de error se solapan, se pueden considerar, estadísticamente, valores iguales. Los valores de las medidas electroquímicas (Figuras 6 y 7a) alcanzan un valor estable, lo que indica que las transformaciones en la capa pasiva son ya escasas.

No es éste el caso de la disolución con cloruros, ya que, a partir de las $5 \mathrm{~h}$ de inmersión (aproximadamente), se produce un aumento de los valores medios tanto de la rugosidad máxima (Figura 3) como de la rugosidad media (Figura 4). Las barras de error (desviación estándar de las medidas) deben entenderse en el entorno del aspecto probabilístico que supone el estudio de cualquier proceso de corrosión: dado que se realizaron un mínimo de cuatro medidas por condición, no en todas ellas se alcanzaron los mismos niveles de rugosidad cuando se sometieron a la disolución con cloruros, por lo que las barras de error son grandes, y en algunos casos, se solapan con la tendencia de los materiales inmersos en disolución sin carbonatar y sin cloruros. Esto puede verse, de forma cualitativa, en las Figuras 1c y 2 . Las imágenes en 3D (Figura 1) son mucho más rugosas, cualitativamente, y la rugosidad aumenta en algunas direcciones tomadas al azar (Figura 2). Este fenómeno se debe al ataque de los cloruros. El contenido en cloruros es suficiente para que el acero no consiga formar una capa pasiva estable, provocando transformaciones en la capa pasiva o el posible inicio de picaduras (a escala nanométrica, aún) en la superficie del acero. La despasivación del acero por los iones cloruro, que conlleva la rotura de la capa pasiva y la pérdida de iones hidroxilo de la disolución, se puede resumir en las reacciones siguientes [1] y [2]: brief times, steel does not reach full passivation, and electrochemical results show the occurrence of transformations on steel surface.

However, from (approx.) 5 h of immersion onwards, the behaviour of steel in both solutions differs noticeably. The steel immersed in a chloride-free solution is clearly observed to hold practically-constant average roughness (Figure 4), thus indicating scarce variations in passivity. Only a slight increase in maximum roughness (Figure 3) is observed from $24 \mathrm{~h}$ of immersion onwards. However, as error bars overlap, they can be considered statistically equal values. The values of the electrochemical measurements (Figures 6 and 7a) reach a stable value, thus indicating that transformations in the passive layers begin to be rather scarce.

This is not the case of the chloride-containing solution, since increased average values are observed in both maximum (Figure 3) and average (Figure 4) values from (approx.) $5 \mathrm{~h}$ of immersion onwards. Error bars (standard deviation of measurements) must be understood as a part of the probability environment involved by the study of corrosion processes. Given that at least four measurements were performed in each condition, the same roughness levels were not reached in all measurements when the samples were subjected to the chloride-containing solution. Therefore, error bars are large and sometimes overlap with the tendency of the materials immersed in the non-carbonated chloridefree solution. This can be observed qualitatively in Figures $1 \mathrm{c}$ and 2; 3D images (Figure 1) are qualitatively much rougher and roughness in some randomly-selected directions increases (Figure 2). This phenomenon is due to chloride attack. Chloride content is enough to prevent steel from forming a stable passive layer, thus causing transformations in the passive layer or the onset of pitting (still at nanometric scale) on steel surface. Steel de-passivation by chloride ions entails the breakdown of the passive layer and the loss of the hydroxyl ions in the solution. It can be summarized in the following reactions [1] and [2]:

$$
\begin{gathered}
\mathrm{Fe}+3 \mathrm{Cl}^{-} \Rightarrow \mathrm{FeCl}^{3-}+2 \mathrm{e}^{-} \\
\mathrm{FeCl}^{3-}+2 \mathrm{OH}^{-} \Rightarrow \mathrm{Fe}(\mathrm{OH})_{2}+3 \mathrm{Cl}^{-}
\end{gathered}
$$

En el perfil de $18 \mathrm{~h}$ se puede apreciar claramente el inicio de una picadura, que aparece marcada un cuadrado en el correspondiente perfil (Figura 2). Esta rotura localizada de la capa pasiva a nivel nanométrico está de acuerdo con el modelo de Marcus et al. (20). Esta rotura puede tener lugar posiblemente en un borde de grano de la misma, causando la formación de un área con
The 18-h profile clearly shows the onset of pitting, which is marked with a square in the corresponding profile (Figure 2). This localized breakdown in the passive layer at nanometric level agrees with the model devised by Marcus et al. (20). This breakdown can occur in a grain boundary, thus causing the formation of an area with a more marked (or corroded) topography. Figure 5 
una topografía más acusada (es decir, más corroída). La Figura 5 apoya este resultado: como se puede apreciar, la superficie empieza a verse afectada por un crecimiento de la rugosidad, y tras $24 \mathrm{~h}$ de inmersión, casi la totalidad de la superficie tiene una rugosidad, medida respecto al punto más profundo del perfil, de un mínimo de $50 \mathrm{~nm}$. Además, los picos de más de $60 \mathrm{~nm}$, casi inexistentes hasta las $10 \mathrm{~h}$ de inmersión, alcanzan un valor importante. Estos valores de rugosidad son compatibles con el aumento de actividad que muestra la medida de $\mathrm{E}_{\text {corr }}$ (Figura 6), así como el continuo descenso de los valores de $R_{p}$ (Figura 7b). Estos parámetros alcanzan valores indicativos de corrosión en el acero en estos horizontes temporales.

El aumento de rugosidad es más notable hasta las $24 \mathrm{~h}$ de inmersión y, a partir de ese tiempo, la variación es más moderada, como se aprecia en la imagen en 3D (Figura 1d) y el perfil mostrado para $36 \mathrm{~h}$ de inmersión (Figura 2). De hecho, el área afectada por la presencia de grandes picos de rugosidad (posibles núcleos de picaduras o de transformaciones de capa pasiva) disminuye a partir de ese instante (Figura 5), lo que implicaría que, a partir de ese momento, el ataque se ralentiza y afecta a mayor parte de la superficie, y la rugosidad media (Figura 4), aún aumentando, se mantiene bastante estable. Esta fase está de acuerdo con las observaciones de Zhang et al. (18): el alto $\mathrm{pH}$ de la disolución, típico de disoluciones sin carbonatar, facilita la repasivación de las picaduras, formándose productos de corrosión que las recubren. En ese periodo, la cinética de crecimiento de las picaduras está más controlada por la caída de potencial a través del depósito de la boca de la picadura (24). Este cierre localizado de las picaduras hace que éstas ya no se puedan percibir con claridad en los perfiles medidos (Figura 2).

\section{CONCLUSIONES}

La técnica de AFM empleada permite ayudar a comprender el comportamiento a corrosión de aceros en medios que simulan los contenidos en los poros del hormigón durante los primeros inicios de la corrosión en este tipo de materiales.

En disoluciones con cloruros, las medidas de AFM muestran una primera etapa de crecimiento epitaxial de la capa pasiva de óxidos/hidróxidos, pese a la actividad electroquímica del material, seguida de una etapa de transformaciones en la capa pasiva por la acción de los cloruros del medio.

\section{AGRADECIMIENTOS}

Este trabajo se ha realizado gracias a la financiación del Ministerio de Ciencia e Innovación, a través del proyecto BIA2007-66491-C02-02. supports this result: the surface is observed to begin to become affected by the growing roughness and, after 24 $h$ of immersion, minimum roughness in almost the whole surface - relative to the deepest valley in the profilereaches $50 \mathrm{~nm}$. Besides, peaks over $60 \mathrm{~nm}$ (almost inexistent until $10 \mathrm{~h}$ of immersion) reach an important value. These roughness values are compatible with the increased activity measured by $E_{\text {corr }}$ (Figure 6), as well as the continuous decrease of $R_{p}$ values (Figure $7 b$ ). These parameters reach indicative corrosion values in steel within these time periods.

Increased roughness is more noticeable up to $24 h$. From that moment onwards, appearance is more moderate, as shown by the 3D image (Figure 1d) and the profile shown for $36 \mathrm{~h}$ (Figure 2). In fact, the area affected by the presence of great roughness peaks (possible clusters of pitting holes or transformations in the passive layer) decreases from this moment onwards (Figure 5). This means that, afterwards, the attack slows down and affects most of the surface, and average roughness (Figure 4) still increases, although it keeps rather stable. This stage agrees with that reported by Zhang et al. (18): the high $\mathrm{pH}$ which characterizes noncarbonated solutions facilitates pitting re-passivation, thus forming the corrosion products which shall recover them. In this period, the growth kinetics of pitting is more controlled by the potential drop through the deposit of the pitting hole (24). This localized closure of pitting holes blurs perceptions in the measured profiles (Figure 2).

\section{CONCLUSIONS}

The AFM technique used allows understanding the corrosion behaviour of steel in different media which simulate the content in concrete pores during corrosion onset in this kind of materials.

In chloride solutions, AFM measurements show a first stage of epitaxial growth in the passive layer of oxides/hydroxides in spite of the electrochemical activity of the material, followed by a stage of transformations in the passive layer due to the action of the chlorides present in the medium.

\section{ACKNOWLEDGMENTS}

The present work was funded by the Spanish Ministry of Science and Innovation through the Project reference BIA2007-66491-C02-02. 


\section{BIBLIOGRAFÍA / BIBLIOGRAPHY}

(1) Alcalde, J. S.; Alcocel, E. G.; Puertas, F.; Lapuente, R.; Garcés, P.: "Comportamiento de morteros de escoria activada alcalinamente con adición de fibras de carbón", Mater. Construcc., vol. 57, no 288 (2007), pp. 33-48.

(2) Miranda, J. M.; Otero, E.; González, J. A.; Hernández, L. S.: "Comportamiento del acero precorroído en solución saturada de Ca(OH)2 y en mortero de cemento. Posibilidades de rehabilitación", Mater. Construcc., vol. 57, no 285 (2007), pp. 5-16.

(3) Zornoza, E.; Garcés, P.; Payá, J.: "Estudio de la velocidad de corrosión de aceros embebidos en morteros de cemento sustituidos con residuo de catalizador de craqueo catalítico (FC3R)", Mater. Construcc., vol. 58, no 292 (2008), pp. 27-43.

(4) Bautista, A.; Blanco, G.; Velasco, F.; Gutiérrez, A.; Palacín, S.; Soriano, L.; Takenouti, H.: "Pasivación de aceros inoxidables dúplex en disoluciones que simulan el hormigón contaminado con cloruros", Mater. Construcc., vol. 57, no 288 (2007), pp. 17-32.

(5) Martínez, I.; Andrade, C.: "Application of EIS to cathodically protected steel: tests in sodium chloride solution and in chloride contaminated concrete", Corros. Sci., vol. 50, no 10 (2008), pp. 2948-2958. doi:10.1016/j.corsci.2008.07.012

(6) Grattan, S. K. T.; Taylor, S. E.; Tong S.; Basheer, P. A. M.; Grattan, K. T. V.: "Monitoring of corrosion in structural reinforcing bars: performance comparison using in situ fiber-optic and electric wire strain gauge systems", IEEE Sens. J., vol. 9, no 11 (2009), pp. 1494502. doi:10.1109/JSEN.2009.2019348

(7) Mietz, J.; Fischer, J.: "Evaluation of NDT methods for detection of prestressing steel damage at post-tensioned concrete structures", Mater. Corros., vol. 58, no 10 (2007), pp. 789-794. doi:10.1002/maco.200704074

(8) Yuyama, S.; Yokoyama, K.; Niitani, K.; Ohtsu, M.; Uomoto, T.: "Detection and evaluation of failures in high-strength tendon of prestressed concrete bridges by acoustic emission", Constr. Build. Mater., vol. 21, no 3 (2007), pp. 491-500. doi:10.1016/j.conbuildmat.2006.04.010

(9) Chang, C. W.; Lien, H. S.: "Expansion stress analysis of ferroconcrete corrosion by digital reflection photoelasticity", NDT\&E Int., vol. 40, no 4 (2007), pp. 309-314. doi:10.1016/j.ndteint.2006.11.003

(10) Mancio, M.; Kusinski, G.; Monteiro, P. J. M.; Devine, T. M.: "Electrochemical and in-situ SERS study of passive film characteristics and corrosion performance of $9 \% \mathrm{Cr}$ microcomposite steel in highly alkaline environments", J. ASTM Int., vol. 6, no 5 (2009), JAI101903 (11) Budiansky, N. D.; Bocher, F.; Cong, H.; Hurley, M. F.; Scully, J. R.: "Use of coupled multi-electrode arrays to advance the understanding of selected corrosion phenomena", Corrosion, vol. 63, no 6 (2007), pp. 537-554. doi:10.5006/1.3278405

(12) Josefowicz, J. Y.; DeLuccia, J. J.; Agarwala, V. S.; Farrington, G. C.: "Atomic force microscopy observations of pitting corrosion and inhibition on 7075-T651 aluminum alloy in hydrochloric acid solutions", Mater. Charact., vol. 34, no 2 (1995), pp. 73-79. doi:10.1016/1044-5803(94)00055-P

(13) Chen, Z. Y.; Guo, X. P.; Zhang, Q.; Qu, J. E.: "AFM and electrochemical study of the effect of dodecylamine on carbon steel corrosion", J. Mater. Sci., vol. 41, no 15 (2006), pp. 5033-5035. doi:10.1007/s10853-006-0104-x

(14) Kowal, K.; DeLuccia, J.; Josefowicz, J. Y.; Laird, C.; Farrington, G. C.: "In situ atomic force microscopy observations of the corrosion behavior of aluminum-copper alloys", J. Electrochem. Soc., vol. 143, no 8 (1996), pp. 2471-2481. doi:10.1149/1.1837033

(15) Jun L.; Lampner, D.: "In-situ AFM study of pitting corrosion of Cu thin films", Colloid. Surface. A, vol. 154, no 1-2 (1999), pp. $227-237$. (16) Veleva, L.; Alpuche-Aviles, M. A.; Graves-Brook, M. K.; Wipf, D. O.: "Comparative cyclic voltammetry and surface analysis of passive films grown on stainless steel 316 in concrete pore model solutions", J. Electroanal. Chem., vol. 537, no 1-2 (2002), pp. 85-93. doi:10.1016/S0022-0728(02)01253-6

(17) Sánchez, J.; Fullea, J.; Andrade, C.; Gaitero, J. J.; Porro, A.: "AFM study of the early corrosion of a high strength steel in a diluted sodium chloride solution", Corros. Sci., vol. 50, no 7 (2008), pp. 1820-1824. doi:10.1016/j.corsci.2008.03.013

(18) Zhang, F.; Pan, J.; Lin, C.: "Localized corrosion behaviour of reinforcement steel in simulated concrete pore solution", Corros. Sci., vol. 51, no 9 (2009), pp. 2130-2138. doi:10.1016/j.corsci.2009.05.044

(19) Freire, L.; Novoa, X. R.; Montemor, M. F.; Carmezim, M. J.: "Study of passive films formed on mild steel in alkaline media by the application of anodic potentials", Mater. Chem. Phys., vol. 114, no 2-3 (2009), pp. 962-972. doi:10.1016/j.matchemphys.2008.11.012

(20) Marcus, P.; Maurice V.; Strehblow, H. H.: "Localized corrosion (pitting): A model of passivity breakdown including the role of the oxide layer nanostructure", Corros. Sci., vol. 50, no 9 (2008), pp. 2698-2704. doi:10.1016/j.corsci.2008.06.047

(21) Boucherit, M. N.; Tebib, D.: "A study of carbon steels in basic pitting environments", Anti-Corros. Method. M., vol. 52, no 6 (2005), pp. 365-370.

(22) Saremi, M.; Mahallati, E.: "A study on chloride-induced depassivation of mild steel in simulated concrete pore solution", Cem. Concr. Res., vol. 32, no 12 (2002), pp. 1915-1921. doi:10.1016/S0008-8846(02)00895-5

(23) Abd El Halem, S. M.; Abd El Aal, E. E.; Abd El Wanees, S.; Diab, E.: "Environmental factors affecting the corrosion behaviour of reinforcing steel: I. The early stage of passive film formation in $\mathrm{Ca}(\mathrm{OH}) 2$ solutions", Corros. Sci., vol. 52, no 12 (2010), pp. $3875-3882$. doi:10.1016/j.corsci.2010.07.035

(24) Cheng, Y. F.; Luo, J. L.: "Metastable Pitting of Carbon Steel under Potentiostatic Control", J. Electrochem. Soc., vol. 146, no 3 (1999), pp. 970-976. doi:10.1149/1.1391707 